The Labore Journal of Economics

$11: 2$ (Winter 2006) pp. 43-70

\title{
Willingness to Pay for Margalla Hills National Park: Evidence from the Travel Cost Method
}

\section{Himayatullah Khan*}

\begin{abstract}
This study, which is among the first in Pakistan to value recreational benefits, estimates the benefits of the Margalla Hills National Park near Islamabad. The study examines how much park visitors are willing to pay to visit the park. Annual benefits from the park are considerable-the total annual consumer surplus or economic benefit obtained from recreation in the park is approximately Rs. 23 million (US $\$ 0.4$ million). Various factors influence the value visitors obtain from the park - these include travel cost, household income, and the quality of the park. Improvements in the quality of the park are estimated to increase recreational benefits by 39\%. The study recommends that a park entrance fee of Rs. 20 per person be introduced, which could be utilized for park management. This would generate nearly Rs. 11 million in revenues annually, a sizable amount of money that represents about 4\% of the annual budget allocated to the environment sector in Pakistan.
\end{abstract}

\section{JEL Classification:}

Keywords: Environmental valuation, willingness to pay, total recreational value, consumer surplus, environmental resources, national parks, Pakistan.

\footnotetext{
* The author is Professor at the Institute of Development Studies, NWFP Agricultural University, Peshawar and currently on deputation to Department of Development Studies, COMSATS Institute of Information Technology, Abbottabad. This paper is based on Himayatullah (2003). The author gratefully acknowledges the financial support provided by the South Asian Network for Development and Environmental Economics (SANDEE). The author also is heavily indebted to Dr. Herath Gunateleka, Prof. Karl G. Maler and Prof. Partha Dasgupta for their valuable criticism, expert comments and suggestions. The study would have never been completed without their help.
} 


\section{Introduction}

Like many other developing countries, Pakistan is seeking to revitalize its tourism sector, including nature tourism to an expanding system of national parks and reserves. In South Asia, Pakistan is one of the poorest in bio-diversity. It has experienced high rates of deforestation in recent years (World Resource Institute, 1996). Forests cover as little as $5 \%$ of the country's area. Due to an ever-increasing population, it is losing more and more forest cover primarily because of conversion of forest to agricultural as well as residential uses. The Government of Pakistan has, in recent years, expressed a serious concern over deforestation and has shown significant interest in the growth of a renowned national park system. Pakistan has a number of national parks, reserves, and wildlife refuges in different parts of the country. Despite the limited number of national parks and reserves, their management is far from satisfactory. This is partly because of insufficient government funds and open access of visitors to these places. Currently, entry to national parks in Pakistan is free. However, revenue can be generated by introducing entry fees that could be spent on the improvement of the quality of the parks. There is a need for a thorough investigation of how these parks can be well managed and how these environmental resources can be valued. No study on the valuation of national parks in Pakistan has ever been conducted.

Natural resource systems such as lakes, rivers, streams, estuaries, forests and parks are used extensively by people for various kinds of recreational activities. Natural resource systems provide valuable services to people. From an economic perspective, these services have two important features. The first is that the economic value of these services depends upon the characteristics of the natural resource system. Knowledge of the values of these services may be important for a variety of resource management decisions. The second important feature is that access to the resource for recreation is typically not allocated through the markets. Rather, access is typically open to all visitors at a zero price or a nominal entrance fee that bears no relationship to the cost of providing access. And there is no or little variation in these access prices over time or across sites to provide data for the econometric estimation of demand functions (Freeman, 1993).

Like other environmental resources and public goods, national parks benefit society in many different ways. According to Isangkura (1998), they not only perform ecological functions but also provide recreational facilities to those who visit these parks. National parks also help enhance precious foreign exchange earnings to national exchequers. Pakistan is very deficient in forest resources because, as mentioned earlier, forests cover only 5 
percent of its area and there are only a few parks in the country. National parks, however, tend to be threatened by forest fire, soil erosion, human settlement inside the parks, pollution created by villagers or visitors to the parks as well as encroachment by local villagers. The overall negative impacts caused by one or another human activities is often associated with the insufficient levels of funding for the management of these parks (Isangkura, 1998).

There are two major sources of funds required for park management. There are the federal and/or provincial government budgetary allocation and revenues generated from park entry fees. The government budget allocated for management of national parks tends to be very limited since it must compete with other developmental programs including education, health care, infrastructure, defense spending, among other programs in the country (Isangkura, 1998). Therefore, the other alternative, fees, can be used to generate additional revenues for park management. At present only a nominal or no entry fee is charged. Charging entry fees for these parks can generate sufficient funds. Furthermore park revenue from entry fees may be increased provided parks are priced suitably. This suggests, given that the federal government budget for National Park management will likely remain small, adjusting park entrance fees may provide the needed park revenue. There is a dire need for their management on a sustainable basis, which in turn requires their correct valuation. The present study probes into the possibility of enhancing park entry fees to account for the recreational benefits that national parks provide tourists. This study focuses on the Margalla Hills National (MHNP) Park, Islamabad.

The present study deals with valuation of the Margalla Hills National Park (MHNP) in northern Pakistan. The data were collected with the help of an on-site sample survey in 2002-03. The study used systematic random sampling method to collect data from a sample of 1,000 visitors. It considered an individual travel cost model for environmental resources in a theoretical framework consistent with the fundamental principles of consumer behaviour. This model was applied to individual household data to estimate the willingness to pay (WTP) for park visitation. It also estimated the price and income elasticities of visitors' demand for park visitation. The study also found that the sample respondents visited the MHNP 9 times per year with their average yearly expenditures on recreation at Rs. 5,500. Their mean monthly income was Rs. 12,000 . The average total cost to the MHNP was Rs. 3,500. About $67 \%$ of the respondents were male and $33 \%$ were female. As many as $60 \%$ were married and $40 \%$ single. The average age of the respondents was 39 years and the average household size was about 7 . More than half $(55 \%)$ of the respondents had primary-level education. 
About $24 \%$ were illiterate. As many as $42 \%$ of sample households were in the income group of Rs.10,000-20,000 per month. More than one-fifth (23\%) of households had a monthly income in the range of Rs.5,000-10,000. Some $20 \%$ of households had income of Rs.20,000-50,000. Trave1 costs incurred by individuals were inversely related to park visitation rates. This implies that the higher the travel cost paid by visitors to reach MHN Park, the less frequently they visit. In addition to travel cost, household income had a positive impact on recreational demand. Visitors with high income were willing to pay 1 more visits to the park. This implies that if the income level of visitors increased, so would the recreational demand. The education of visitors had a positive sign while the age variable had a negative sign. However, both these variables had insignificant coefficients. The paper also found that the total consumer surplus was equal to Rs. 23.2 million and total recreational value 200.1 million. The paper compared the present consumer surplus and total recreational value with those in a projected scenario and concluded that if the quality of the park were improved it would yield yearly consumer surplus and total recreational value to the tune of Rs.32.01 million and 208.9 million, respectively.

The overall goal of the study is to measure the recreational value of the Margalla Hills National Park, Islamabad, Pakistan. The specific objectives of the study are to: (a) investigate if there exists the usual functional relationship between travel cost (p) and park visitation (q); (b) determine factors that affect the visitors' willingness to pay (WTP) for recreational services of the park; (c) estimate the consumer surplus and recreational value (benefits) of the MHN Park; (d) find out whether improvement in recreational benefits of the park would lead to a higher demand for park visitation; and (e) suggest policy recommendations as to how overall benefits of the park can be improved.

\section{Literature review}

There is a growing body of literature that focuses on valuing ecotourism and wilderness areas in developing countries. The primary approaches used in these studies -Travel Cost (TC) Method and Contingent Valuation (CV) - were both pioneered in the United States and have only recently been applied in developing countries. The TC approach assumes that various factors affecting visitors' travel costs, including both direct costs and the opportunity costs of visitors' time, influence the length and frequency of visitation to a given destination. The TCM has limitations, particularly in applications to multiple destination trips (Pearse, 1968). Because the TCM is an indirect valuation method and is based on actual costs and in case of multiple destination trips it is difficult to segregate the 
cost for a particular site. In addition, assumptions such as the homogeneity of marginal costs and preferences of visitors from each origin are questionable (Wennergen, 1964). To circumvent such limitations, studies that have estimated use values of protected areas in developing countries have often excluded nonresidents (Durojaiye and Ipki, 1988; Tobias and Mendelssohn 1991), or if foreign visitors are included, restrictive simplifying assumptions have been imposed (Mungatana and Navrud, 1994). While studies using TC have provided useful insights into the value of ecotourism in protected areas in developing countries, they have typically focused more on estimating consumer surplus than on evaluating user fees as a guide toward designing improved park pricing strategies, the primary objective of this study.

On the contrary, $\mathrm{CV}$ relies on surveys containing hypothetical valuation scenarios in order to generate values for goods that cannot be priced directly through a market (Cummings, Brookshire, and Schulze, 1986). Thus, CV has more flexibility than TC in that a survey can be designed to elicit many different types of values, not only the use value of a specific area such as a national park. Although CV has been applied to developing countries less often than TC (Lindberg and Johnson, 1994), there is growing recognition of the importance of these applications, particularly when results have direct implications for natural resource management and policy. CV has been used to measure total preservation value, which includes both use and non-use components (Echeverria, Hanrahan, and Solorzano, 1995). Use values have been examined through analyses of the explanatory factors influencing W'TP for increases in entrance fees and trip costs as well as improvements in park amenities (Abala, 1987; Baldares and Laarman, 1990; Moran, 1994; Shultz, Pinnazo, and Cifuentes, 1997). It is important to note that both CVM and TCM are alternative methods of valuation. CVM is also known as stated-preference method where the respondents just state their preference in a hypothetical situation. On the other hand, the TCM is also called indirect or revealed-preference method and the respondents report what he or she has actually paid.

Relevant literature also shows the superiority of TCM over CVM (Freeman, 1993; Koasa-ard et al. 1995 and Garrod and Willis, 1999; Arin and Sills, 2001; and Ward and Beal; 2000. The present study uses TCM for estimating consumer surplus as well as total consumer value. It also uses CVM to find out how the visitors will behave if the quality of park were improved. Thus a combination of TCM and CVM is used in this study. 
There are a number of environmental valuation studies but only some have used the economic approach to calculate welfare measurement ${ }^{1}$. The Lumpinee Park study by Grandstaff and Dixon (1986) and a joint study by Thailand Development Research Institute (TDRI) and Harvard Institute for International Development (HIID) on Khao Yai National Park (Kaosa-ard, Patmasiriwat, Panayotou, and Deshazo, 1995) are two main studies conducted in Thailand which have used economic valuation methods. Both studies have combined the travel cost method (TCM) with the open-ended contingent valuation method (CVM) to assess willingness to pay (WTP).

Chase et al. (1998) studied ecotourism demand and differential pricing of natural park access in Costa Rica. The study presents a conceptual framework and empirical analysis of the impacts of introducing a differential entrance fee policy at three national parks in Costa Rica. Contingent behavior methodology has been designed to elicit information on foreign tourists' hypothetical park visitation behavior at alternative entrance fee levels. The study has also estimated park visitation demand functions and price and income elasticities. It has also discussed revenue maximizing fees and applications of differential pricing principles to park management in Costa Rica. As a case study, Chase et al. (1988) contributes to an understanding of the role that economic analysis can play in the management of protected areas.

Grandstaff and Dixon (1986) used the zonal TCM and found the consumer surplus of Lumpinee Park use value to be 132 million bahts. Similarly, the CVM found this value to the tune of 130 million bahts.

Kaosa-ard et al. (1995) used the TCM to measure the Khao Yai National Park use value and the CVM method to measure its nonuse value. The TCM estimates showed the direct benefit of 1,420 bahts per visit, of which 870 bahts is the consumer surplus. The average WTP for entrance fee is 22 bahts per person. The average WTP after some improvements is 44 bahts per person. The average nonuse value for Thais and non-Thais is 730 bahts and 183 bahts respectively per person per year. These findings indicated that the value of Khao Yai National Park was certainly positive and of a reasonable magnitude. This suggests some positive marginal benefit of park improvements. When compared to the marginal cost, it indicated that park improvements would yield a net gain to society.

\footnotetext{
${ }^{1}$ For further details about environmental valuation methods, see Bateman and Willis (1999) and Freeman (1993).
} 
Another study (Isangkura, 1998) used the contingent ranking method to measure the value of environmental benefits of three recreational areas in northern Thailand. The study found that it was easier for the respondents to indicate their preferences in the contingent-ranking format than in the open-ended WTP format. The parameter estimates from the indirect utility function were used to calculate the welfare gains derived from visiting these recreational areas. These welfare gains were then used to determine the entrance fees. The findings of the study showed that an increase in the entrance fees would raise park revenues. The study suggested that increased revenue could be used for recreational management and would help ensure the continuity of recreational services provided by national parks in Thailand.

Arin and Sills (2001) studied developing tourism in the national parks of the Republic of Georgia. The study used CVM to determine potential revenue capture by the park, with a split sample evaluating the impact of 'annual pass' vs. 'daily entrance fee' payment vehicle on WTP and on expected numbers of and length of visits. The study found that approximately $70 \%$ of the respondents would visit at least once in the coming year. The probit model results showed that more educated younger residents of Tbilisi with large budgets for leisure activities were more likely to visit the parks. The mean predicted expenditures per trip (excluding park fee) were 150 lari $(2$ lari $=$ US \$1) with significant explanatory factors including city of residents and trave1 preferences. According to this study the model of WTP for an annual pass had a greater number of significant coefficients on variables theoretically and intuitively expected to influence WTP, including size of household, car ownership, leisure budget, and number of past visits to natural areas. The study found that older respondents' and women's W'TP were less as were households who listed picnicking as one of their outdoor activities. These results suggest that respondents might have better understood the annual pass payment vehicle.

The review of relevant studies shows that even though some studies (Grandstaff and Dixon, 1986 and Kaosa-ard, et. al., 1995) carefully measured the environmental benefits, these two studies focused on a single park and did not include park substitutability in their analysis. Only one study undertaken in Thailand (Isangkura, 1998) was based on the multi-park system. Studies conducted in other developing countries, though somewhat better, suffered from methodological limitations of one type or another. For example, some studies have not used the correct time value, or ignored relevant explanatory variables in their analysis. Some have used small sample size and others have not covered latest published studies in their review. No 
such study has ever been conducted in Pakistan. The present study, which studies valuation of the MHN Park, Islamabad will be the first of its nature in Pakistan and can be considered as pioneering work in park valuation in this country.

\section{Research methods}

Three different approaches are used to estimate recreational values of such environmental resources: Productivity changes method, contingent valuation methods (CVM), and travel cost methods (TCM). From a utility perspective, the value arising from the change in production approaches ignores the consumer surplus generated by the recreation experience, and as a result underestimates the total value of the recreation experience (Seenprachawong, 2001). Most studies of parks use the TCM and CVM to estimate the consumer surplus of visitors (Nam and Son, 2001).

Conventional household production function (HPF) models investigate changes in the consumption of commodities that are substitutes or complements for each other. This framework can be extended to derive an indirect mechanism for evaluating individual preferences for, and consumption of, non-market goods. The travel-cost method (TCM) is a prominent example of an HPF-type approach and uses the cost of traveling to a non-priced recreation site as a means of inferring the recreational benefits that the site provides. TCM studies have consistently shown that as the price of access (cost of travel) increases, the visit rate to the site falls. The TCM is usually estimated as a trip generating function where the visit rate depends upon the cost of travel to the site, travel costs to substitute sites, and other socio-economic characteristics of the visitors (Garrod and Willis, 1999). This study employs the TCM.

\section{Theoretical Framework}

This study follows Freeman's approach (1993) and assumes that the individual's utility depends on the total time spent at the site (MHN Park in this case), the quality of the park, and the quantity of the numeraire. With the duration of the visit fixed for simplicity, the time on site can be represented by the number of visits. The individual solves the following utility maximizing problem ${ }^{2}$ :

$$
\operatorname{Max} \mathbf{u}(\mathrm{X}, \mathrm{r}, \mathrm{q})
$$

Subject to the twin constraints of monetary and time budgets:

${ }^{2}$ This section draws heavily on Freeman (1993) and Ward and Beal (2000). 


$$
\begin{aligned}
& \mathrm{M}+\mathrm{p}_{\mathrm{w}} \mathrm{t}_{\mathrm{w}}=\mathrm{X}+\mathrm{cr} \\
& \text { and } \\
& \mathrm{t}^{*}=\mathrm{t}_{\mathrm{w}}+\left(\mathrm{t}_{1}+\mathrm{t}_{2}\right) \mathrm{r}
\end{aligned}
$$

Where $\boldsymbol{X}$ shows the quantity of numeraire whose price is one, $\boldsymbol{r}$, number of visits to the MHN Park, $\boldsymbol{q}$, environmental quality at the site, $\boldsymbol{M}$, exogenous income, $\boldsymbol{p}_{w}$, wage rate, $\boldsymbol{c}$, monetary cost of a trip, $\boldsymbol{t}^{*}$, total discretionary time, $\boldsymbol{t}_{w}$, hours worked, $\boldsymbol{t}_{1}$, round-trip travel time, and $\boldsymbol{t}_{2}$, time spent on site.

We assume that $\boldsymbol{r}$ and $\boldsymbol{q}$ are weak complements in the utility function implying that the number of visits will be an increasing function of the site's environmental quality. The time constraint reflects the fact that both travel to the site and time spent on the site take time away from other activities. Thus there is an opportunity cost to the time spent in the recreation activity. We also assume that the individual is free to choose the amount of time spent at work and that work does not convey utility (or disutility) directly. Thus the opportunity cost of time is the wage rate. Finally, we also assume that the monetary cost of a trip to the site has two components: the entry fee $\boldsymbol{f}$, which could be zero, and the monetary cost of trave1. This cost is $\boldsymbol{p}_{d} \boldsymbol{d}$, where $\boldsymbol{p}_{\boldsymbol{d}}$ is per-mile cost of travel and $\boldsymbol{d}$ is the distance to the site and return from it.

Substituting equation (3) into (2) yields:

$$
M+p_{\mathrm{w}} \mathrm{t}^{*}=\mathrm{X}+\mathrm{p}_{\mathrm{r}} \mathrm{r}
$$

where $\boldsymbol{p}_{\boldsymbol{r}}$ is the full price of a visit given by

$$
\begin{aligned}
p_{\mathrm{r}} & =\mathrm{c}+\mathrm{p}_{\mathrm{w}}\left(t_{1}+t_{2}\right) \\
& =\mathrm{f}+\mathrm{p}_{\mathrm{d}} d+p_{\mathrm{w}}\left(\mathrm{t}_{1}+\mathrm{t}_{2}\right)
\end{aligned}
$$

As equation (5) makes clear, the full price of a visit consists of four components: the entry fee, the monetary cost of travel to the site, the time cost of travel to the site, and the cost of time spent at the site. On the assumption that individuals are free to choose the number of hours worked at a given wage rate, the two time costs are valued at the wage rate.

Maximizing equation (1) subject to the constraint of equation (4) will yield the individual's demand functions for visits:

$$
r=r\left(p_{\mathrm{r}}, M, q\right)
$$


If all individuals spend the same amount of time at the site, and have the same wage, then this component of the price of a visit is the same for all individuals. Given these assumptions, the data on rates of visitation, travel costs, and variation in entry fees (if any) can be used to estimate the coefficient on $\boldsymbol{p}_{\boldsymbol{r}}$ in a travel cost-visitation function. Because of the linearity of equation (5), the coefficient on $\boldsymbol{p}_{\boldsymbol{r}}$ can be used to derive the individual's demand for visits to a site as a function of the entry fee.

We further assume that there are substitute sites available. In such cases, the interactions and the substitution effects among sites must be modeled explicitly. This calls for some form of multi-site model. Multi-site models are estimated as systems of demand equations. For each site $\boldsymbol{j}(\boldsymbol{j}=$ $1, \ldots, j, \ldots, m)$, a demand equation of the following form is specified:

$$
\begin{aligned}
r_{j i} & =r_{j}\left(p r_{j i}, p r_{k i}, M_{i}, q_{j}\right) \\
i & =(i=1, \ldots i, \ldots, s),(k=1, \ldots, k, \ldots, m), \text { and } k \neq j(7)
\end{aligned}
$$

Where $\boldsymbol{r}_{j i}$ is the number of visits individual $i$ makes to the site, $p r_{j i}$ is the full price of a visit by $i$ to $j$, and $p r_{k i}$ is the set of substitute prices for visits to other sites. This type of model can be estimated from data on individual observations (see, for example, Freeman 1993 and McConnell, 1985).

\section{Variables and data}

Economic theory and the considerable experience of recreation managers have shown that demographic and other independent variables are thought to influence recreation visitation. Apart from demographic variables, the most important variables include travel cost, travel time, substitute sites and site quality and congestion. Demographic variables such as age, sex, education, income, employment status, rural versus urban residence, and family size are thought to affect recreational demand.

Intuitively, age would appear to be an important determinant of demand for park visitation and is expected to be inversely related. That is, as age increases, participation decreases. Sex may be another determinant. We expect that men are more likely to participate than women. Regarding education, people with higher education would appear to appreciate outdoor nature-based activities more than people with less formal education. Household income has also, generally, been found to have a positive correlation with participation in many outdoor recreational activities. We expect that the higher the household income, the higher will be the 
number of park visitations. Urban dwellers are likely to participate more than people from rural areas. A park of better quality may attract an individual more often than one of poor quality.

Trave1 costs also affect outdoor recreational demand. The relationship between travel cost and park visitation may be negative. On the question of what costs should be included, some researchers have closely investigated the costs of fuel, oil, tires, repairs and maintenance for vehicles to estimate appropriate travel costs. Seller, Stoll and Chavas (1985) used the cost of food, accommodation and fuel costs. Beal (1995) also found that the majority of respondents considered fuel, food, and accommodation costs as relevant to their trip decision. Regarding the value of on-site time, McConnel (1992) argued that the opportunity cost of on-site time should be included in the price variable. McConnel concluded that accounting for on-site time presents such a difficult problem that no systematic method had been developed, either conceptually or empirically. Smith, Desvousges and McGevney (1983) suggested that cost would be some proportion $k$ of each individual's wage rate. Prices of substitute sites also affect recreational demand of the MHN Park. Some visitors may believe that each national park is unique and has no substitute. Conversely, for some people other forms of outdoor recreation (such as going to a movie) are substitutes for nature-based recreation in national parks. Freeman (1993) approached the substitute site dilemma by suggesting researchers ask visitors which other single site is visited frequently and include only that site's price as the relevant substitute price. He asserted that a next-best site yielding similar characteristics (a national park in this case) is the appropriate alternative. Ayubia National Park $^{3}$ in Galliat was identified as the closest substitute site for the MHN Park. It is located about 40 miles from MHNP. Site quality may also affect park visitation. The higher the site quality perceived by visitors, the higher will be the consumer benefits.

${ }^{3}$ Ayubia National Park is located North of Murree in the Himalayan Range Mountains. Ayubia, consisting of four hill stations, namely, Khaira Gali, Changla Gali, Khanspur and Gora Dhaka, is spread over an area of 26 kilometers. These hill stations have been developed into a hill resort known as Ayubia. The chairlifts provided at this place are a matter of great attraction. It is an important place from the viewpoint of wild life, nature, ecotourism, and education. This park provides refuge to the elusive leopard and the black bear. Bird-watching is excellent here. There are steep precipices and cliffs on one side and on the other are tall pine trees. Wild animals are also found in the thick forests around. Mammals in the park include Asiatic leopard, black bear, yellow throated marten, Kashmir hill fox, red flying squirrel, Himalayan palm civet, masked civet and rhesus macaque. Birds in the park are golden eagle, griffin vulture, honey buzzard, peregrine falcon, kestrel, Indian sparrow hawk, hill pigeon, spotted dove and collared dove. 
The data were collected by conducting a site-level survey during 2002-03. The sample size was 1000 respondents. Regarding sampling, Scheaffer et al. (1996) states that: "A systematic sample is generally spread more uniformly over the entire population and thus may provide more information about the population than an amount of data contained in a simple random sample." This study used systematic random sampling where every $10^{\text {th }}$ visitor was interviewed. In case of his/her refusal another visitor was interviewed. The sampling was arranged to reflect changes in seasonal uses of the park $(34 \%$ in spring, $22 \%$ in summer, autumn and winter, respectively), as it is believed that visitors come to the MHN Park for recreation more in spring than in any other season.

\section{Econometric Models}

Economic theory does not suggest any particular functional form for TCMs. The most common practice is to statistically test various functional forms such as:

$$
\text { linear }
$$

$$
v=\alpha+\beta P
$$

$$
\text { log-linear }
$$$$
\log v=\alpha+\beta P
$$

$$
\text { double-1og }
$$$$
\log v=\alpha+\log \beta P
$$

$$
\text { negative exponential } \quad v=\alpha+\log \beta P
$$

The estimated consumer surplus for an individual making $\mathrm{v}$ visits to the site in case of the linear form is given by $\mathrm{CS}=-\mathrm{v}^{2} / 2 \beta$. The linear functional form implies finite visits at zero cost but has a critical cost above which the model predicts that negative visits will be demanded. However, the consumer surplus in case of $\log$-linear is given by CS $=-\mathrm{v} / 2 \beta$. This implies a finite number of visits at a zero cost and never predicts negative visits, even at a very high cost (Garrod and Willis, 1999). This study reports the estimated results of the linear functional form, as these were the best fit as compared to those found by estimating $\log$-lin, double $\log$ functional forms.

The basic model used in this study depicts the number of visits to the MHN Park as a function of factors such as the travel cost, time spent in traveling, substitute sites, income, education, age, sex, rural versus urban residence, family size, site quality and employment status. Thus, the mode1 may be specified as follows: 


$$
\begin{aligned}
& v_{i}=\beta_{0}+\beta_{1} T C_{i}+\beta_{2} Y_{i}+\beta_{3} S T_{i}+\beta_{4} A_{i}+\beta_{5} E_{i} \\
& +\beta_{6} F S_{i}+\beta_{6+k} \sum_{k=1}^{3} D_{k}+e_{i}
\end{aligned}
$$

where $V_{i}$, the dependent variable stands for the number of visits by the $i t h$ individual to the MHN Park per period of time; $T C$ for round trip total cost (Rs) to the site including travel time; $\boldsymbol{Y}$ for household income (Rs./month); $\boldsymbol{S} \boldsymbol{T}$ for travel cost to and from a substitute site; $\boldsymbol{A}$ for age of the visitor; $\boldsymbol{E}$ for highest level of education gained by the visitor; $\boldsymbol{F S}$ for family size; $\boldsymbol{D}_{1}$ for 1 if male and 0 otherwise; $\boldsymbol{D}_{2}$ for 1 if urban dweller and 0 otherwise; $\boldsymbol{D}_{3}$ for 1 if the visitor's perception about the site's recreational facilities is good and 0 if bad.

\section{Description of the Study Site}

The Margalla Hills National (MHN) Park constitutes the area of this study. The MHN Park is spread over an area of about 15,800 hectares. It is situated on the northern, eastern and western sides of Islamabad. It includes the Margalla Hills, Rawal Lake and Shakar Parian and was given the status of a national park in 1980 after the government recognized the growing threat to its flora and fauna. Of the three distinct units, the largest area, the Margalla Hills, of approximately 12,600 hectares has been affected by villagers living in direct contact and depending on the fertility of the land. The proper conservation of the area will gradually re-establish the environment to its natural state providing prospects for outdoor recreation in "unspoiled" nature with a focus on wildlife viewing, hiking and camping. The Margalla Hills consists of mountain wilderness, an urban recreation and cultural centre, and a large reservoir. The Rawal Lake of approximately 1,900 hectares represents a man-made park environment, which has the appearance of a natural ecosystem. To provide a continuous supply of drinking water, city planners reestablished part of a pre-historic lake, which created a rare opportunity for the population in the Capital Territory to experience a lake environment and waterfowl, enjoy sports in addition to common outdoor recreation activities such as picnics, strolls and jogging. It has a $2-\mathrm{km}$ perimeter around the lakeshore buffer, which is a domestic water supply, waterfowl habitat, and recreational area. Shakar Parian, covering approximately 1,300 hectares represents an urban recreational and cultural park and provides the urban population with an excellent recreational facility for activities such as sports, jogging, strolls and picnics. 
The Park is a habitat for various species of animals and birds. The gray goral, barking deer, monkey, kalij, grey and black partridges and chir pheasants particularly arouse the interest of wild life enthusiasts. The Margalla Hills Park provides an excellent opportunity for bird watching. A chir pheasant hatchery has been established at Chak Jabri to raise captive chir pheasants that have become extinct in the hills. These are then released in the wild. Other mammals in the park include the Asiatic leopard, wild boar, jackal, rhesus macaque, leopard cat, gray goral sheep, chinkara gazelle (rare), red fox, pangolin, porcupine, yellow throated marten and fruit bats. Reptiles in the park are russelles viper, Indian cobra and saw scaled viper. Other birds in the park are the griffin vulture, laggar falcon, peregrine falcon, kestrel, Indian sparrow hawk, Egyptian vulture, white cheeked bulbul, yellow vented bulbul, paradise flycatcher, golden oriole, spotted dove, collared dove, larks, shrikes, and buntings.

\section{Empirical results and discussion}

The descriptive statistics of the sample respondents and the reasons for visiting the MHNP are given in Table-1 and Table-2, respectively. Nearly three-quarters $(73 \%)$ of the visitors came to Islamabad for recreational purposes. Some $13 \%$ of visitors reported traveling as the reason for coming to Islamabad. As many as $42 \%$ of sample households fall in the income group of Rs.10,000-20,000 per month. More than one-fifth (23\%) of households have monthly income in the range of Rs.5,000-10,000. Some $20 \%$ households have income of Rs.20,000-50,000. Taken together $65 \%$ households fall in the income range of Rs.5,000-20,000. Half of the visitors visited the park up to 2 times and $34 \%$ between $3-5$ times a year. The percentage of visitors, who visited the park 6-10, 11-5, and 16-20 times a year, was $11 \%, 3 \%$ and $2 \%$, respectively (Figure 1). The sample mean of visits was 7 . Half the respondents considered the quality of the park as good compared to $35 \%$ who believed it bad or very bad, with about $15 \%$ answering with 'don't knows'. These figures demonstrate that the majority of the visitors were happy with the recreational quality of the park. The majority $(60 \%)$ of the visitors were from urban areas compared to $40 \%$ of the visitors who were from rural areas. Similarly, more than $62 \%$ of the respondents wanted an improvement in the quality of services of the park. On the question about how more resources should be allocated for park management, $38 \%$ of the respondents preferred an increase in entrance fee, $40 \%$ chose reallocation of the government budget, and $22 \%$ advocated voluntary donations towards the parks' management funds. 
Table-1: Descriptive Statistics of the Respondents

\begin{tabular}{|c|c|c|c|}
\hline Variables & Mean & Minimum & Maximum \\
\hline No. of Recreational Trips & 9.00 & 1.00 & 20.00 \\
\hline Yearly Spending on Ecotourism (Rs) & 5,500 & 1,000 & 10,000 \\
\hline Household Monthly Income (Rs) & 12,000 & 4,900 & 100,500 \\
\hline Distance $(\mathrm{Km})$ & 30 & 1.12 & 90.45 \\
\hline No. of Trips to MHN Park & 7 & 1 & 15.00 \\
\hline No. of Trips to Substitute Parks & 1.61 & 1.00 & 5.00 \\
\hline Age (Years) & 38.95 & 17.00 & 65.60 \\
\hline Household Size & 6.80 & 4.34 & 11.35 \\
\hline \multicolumn{4}{|l|}{ Sex: } \\
\hline Male & $67 \%$ & & \\
\hline Female & $33 \%$ & & \\
\hline \multicolumn{4}{|l|}{ Marital Status: } \\
\hline Married & $60 \%$ & & \\
\hline Single & $40 \%$ & & \\
\hline \multicolumn{4}{|l|}{ Education: } \\
\hline None & $24 \%$ & & \\
\hline Primary & $55 \%$ & & \\
\hline Secondary & $11 \%$ & & \\
\hline Technical diploma & $3 \%$ & & \\
\hline Bachelor's Degree & $5 \%$ & & \\
\hline Graduates & $2 \%$ & & \\
\hline \multicolumn{4}{|l|}{ Residence: } \\
\hline Urban (mainly from Islamabad and & $60 \%$ & & \\
\hline Rawalpindi) & $40 \%$ & & \\
\hline Rural & & & \\
\hline \multicolumn{4}{|l|}{ Do you want improvement in quality? } \\
\hline Yes & $62 \%$ & & \\
\hline No & $38 \%$ & & \\
\hline \multicolumn{4}{|l|}{ How should the money be raised? } \\
\hline Increase entry fee & $38 \%$ & & \\
\hline Govt. budget reallocation & $40 \%$ & & \\
\hline Donation & $22 \%$ & & \\
\hline
\end{tabular}

Source: Survey 
Figure-1: Frequency Distribution of the Trips to MHNP during Last 12 months

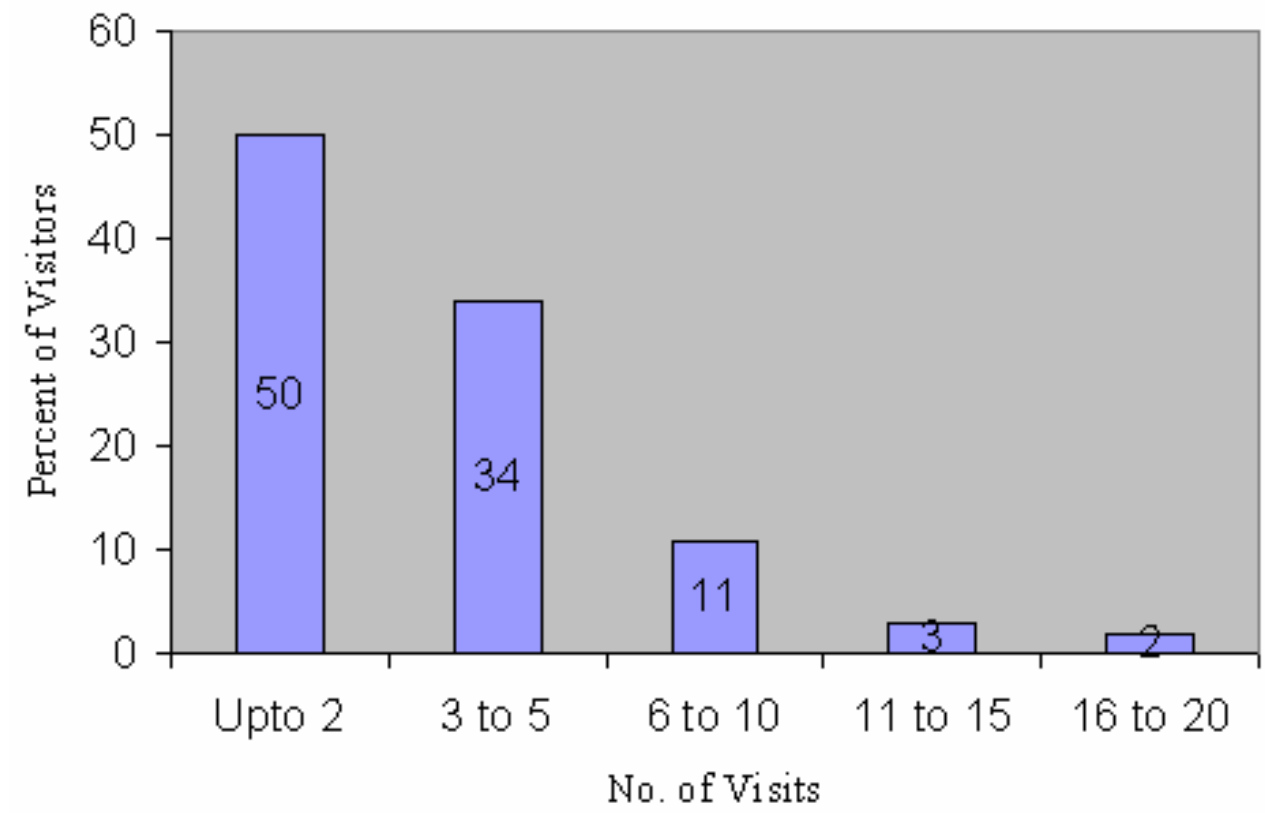

Table-2: Reasons for Visiting MHN Park by Sample Respondents

\begin{tabular}{|c|c|c|}
\hline Reasons to Visit Park & No. of Respondents & Percent \\
\hline Sightseeing & 50 & 5 \\
\hline Walking & 40 & 4 \\
\hline Bird watching & 30 & 3 \\
\hline Relaxation & 40 & 4 \\
\hline Exercising & 60 & 6 \\
\hline Eating Seafood & 100 & 10 \\
\hline Swimming & 40 & 4 \\
\hline Boating & 20 & 2 \\
\hline Combination & 620 & 62 \\
\hline Al1 & 1000 & 100 \\
\hline
\end{tabular}

Source: Survey. 
Variables were included on the logic of the underlying economic theory. First the variables were tested for correlation. According to Loomis and Walsh (1997), an absolute value of 0.8 signifies multicollinearity. The correlation matrix displayed in Table-3 shows no correlation higher than 0.47 , which indicates that multicollinearity is not a problem within our data set. All variables could thus initially be included in the analysis.

Table- 4 reports the results of the travel cost regression model in a linear fashion. In these models, most coefficients have the expected signs. The coefficient on travel costs is negative and statistically significant. Similarly, the coefficient on household income is statistically significant and positive. The coefficient on substitute site is also positive but statistically insignificant.

As expected, high travel costs incurred by individuals are inversely related to the park visitation rate. This implies that the higher the travel cost paid by visitors to reach the MHN Park, the less the frequency of their visits. We may thus infer that there is less demand to visit the park by those visitors who live far away from it compared to those who live close to the park. This finding is in line with Nam and Son (2001), Landsdell and Gangadharan (2001) and Nillesen (2002).

In addition to travel cost, household income has a positive impact on recreational demand and has the correct algebraic sign. Visitors with high income are willing to pay more visits to the park. This implies that if the income level of the visitors increases so will the recreational demand.

Table-3: Correlation Matrix of Variables

\begin{tabular}{|c|c|c|c|c|c|c|c|}
\hline Variables & $\begin{array}{c}\text { No. of } \\
\text { Visits V } \\
\end{array}$ & $\begin{array}{c}\text { Travel } \\
\text { Cost TC }\end{array}$ & $\begin{array}{c}\text { Income } \\
\text { I }\end{array}$ & $\begin{array}{c}\text { Substitute } \\
\text { Cost SC }\end{array}$ & $\begin{array}{c}\text { Education } \\
\text { Edu } \\
\end{array}$ & $\begin{array}{c}\text { Age } \\
\mathbf{A}\end{array}$ & $\begin{array}{c}\text { Household } \\
\text { Size HS } \\
\end{array}$ \\
\hline V & 1.00 & -0.39 & 0.06 & 0.41 & 0.37 & -0.13 & -0.47 \\
\hline $\mathrm{TC}$ & -0.39 & 1.00 & -0.37 & 0.09 & -0.17 & -0.23 & 0.21 \\
\hline I & 0.06 & -0.37 & 1.00 & 0.35 & 0.46 & 0.39 & 0.41 \\
\hline SC & 0.41 & 0.09 & 0.35 & 1.00 & -0.18 & -0.15 & -0.19 \\
\hline Edu & 0.37 & -0.17 & 0.46 & -0.18 & 1.00 & 0.43 & 0.35 \\
\hline Age & -0.13 & -0.23 & 0.39 & -0.15 & 0.43 & 1.00 & 0.38 \\
\hline HS & -0.47 & 0.21 & 0.41 & -0.19 & 0.35 & 0.38 & 1.00 \\
\hline
\end{tabular}


Table-4: Estimated Results of Linear Regression Equations

\begin{tabular}{lr}
\hline \multicolumn{1}{c}{$\begin{array}{c}\text { Variable } \\
\text { Dependent Variable }\end{array}$} & $\begin{array}{c}\text { Coefficients (t-stats) } \\
\text { No. of Visits }\end{array}$ \\
\hline Intercept & $2.35(3.12)$ \\
Trave1 Cost & $-0.04(-2.68)^{* * *}$ \\
Household Income & $0.0053(2.13)^{* *}$ \\
Price of Substitute & $0.00021(1.79)$ \\
Age & $-0.014(-1.49)$ \\
Education & $0.0089(1.37)$ \\
Family Size & $0.0009(0.15)$ \\
Dummy1 (1 for Male) & $0.366(1.34)$ \\
Dummy2 (1 for Urban Dweller) & $0.008(1.20)$ \\
Dummy3 1 if Visitor's Perception is Good & $0.035(2.13)^{* *}$ \\
$R^{2}$ & 0.53 \\
F.Statistics & 12.7 \\
\hline
\end{tabular}

$* *$, and $* * *$ indicate significance at $5 \%$ and $1 \%$ level, respectively.

There is no significant relationship between the cost of substitute sites and the demand for the MHN Park. This is not in line with the economic demand theory that the demand for a site will increase if prices of substitute sites increase. This may be due to the fact that the MHN Park has no perfect or close substitutes. We, however, tried to get some crude estimates of the price of a substitute site. It is however important to note that the coefficient of the substitute price has the expected positive sign. Education of visitors bears a positive sign while the age variable has a negative sign. However, both these variables have insignificant coefficients. The dummy variables for male, urban dweller and good perception of visitors about the environmental quality of the park have positive coefficients. However, only the latter dummy has a statistically significant coefficient. This implies that if the quality of services of the MHN Park were improved, visitors would wish to pay more visits to the park. We have also explored the possibility of the demand curve for the MHN Park shifting upwards to the right if its quality is improved. This is shown in Figure 2.

Most of the coefficients have the expected signs. According to the $\mathrm{R}^{2}$ statistic, about $50 \%$ of the total variation in the dependent variable is explained. 


\subsection{Demand curves}

Two linear demand curves for MHN Park visitation were estimated from the survey data that are shown in Figure 2. The actual user demand for the MHN Park is represented by equation 9 and as the lower curve in Figure 2. Similarly a hypothetical demand for the MHN Park in case of improvement in the quality of park services is given by equation 10 and the upper curve in Figure 2. This implies that improvement in the quality of the services of the park would shift the demand curve upward to the right.

$$
\begin{aligned}
& \mathrm{v}_{\mathrm{i}}=38.16-0.011 \mathrm{tc}\left(\mathrm{R}^{2}=0.6813\right) \\
& \mathrm{v}_{\mathrm{i}}=47.39-0.0129 \mathrm{tc}\left(\mathrm{R}^{2}=0.5786\right)
\end{aligned}
$$

Figure-2: Park Visitation Demand Curves

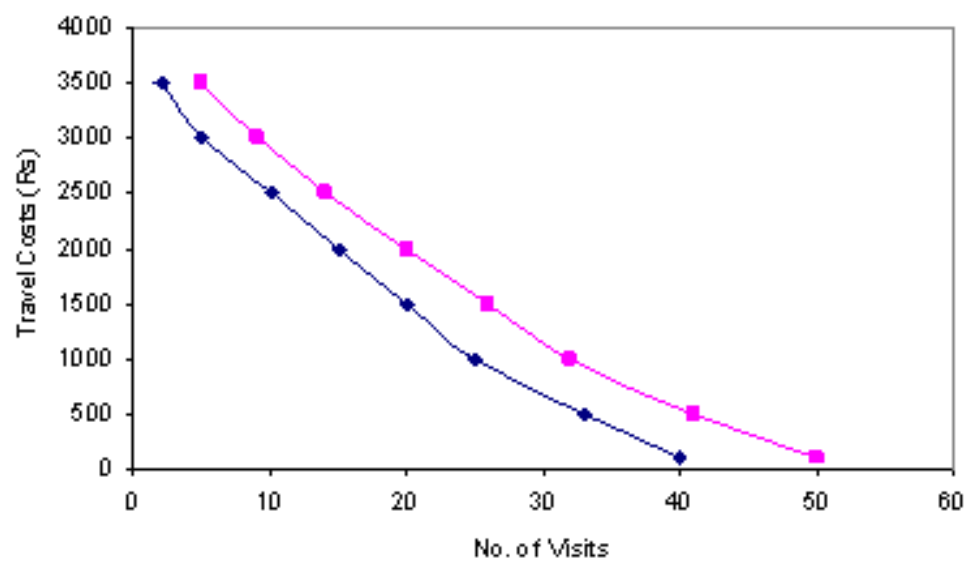

$\rightarrow-$ Visits Without Im provem ent $\rightarrow$-Visits With Improvement

\subsection{Demand Elasticities}

For any particular park, elasticities of park visitation demand can be calculated from the marginal effects associated with the estimated demand coefficients. The estimated elasticities associated with the own-price, crossprice, and income variables are shown in Table- 5 . As is customary, the ownprice elasticity is negative and is found to be significant at the $99 \%$ confidence level. This is due to the inverse relationship between travel costs (price) and visitation demand (quantity). Cross price elasticity is positive but insignificant. This may be due to the reason that there are no close substitute sites or the visitors may not correctly reveal their preference for different parks. Finally, the demand for MHN Park visitation is (statistically significant) income elastic. 
Table-5: Estimated Elasticities of Park Visitation Demand

\begin{tabular}{lr}
\hline \multicolumn{1}{c}{ Elasticity } & \multicolumn{1}{c}{ MHN Park } \\
\hline Own-Price & $-1.15^{* * *}(3.12)$ \\
Cross-Price & $0.28(1.67)$ \\
Income & $0.087^{* *}(2.36)$ \\
\hline
\end{tabular}

*** Significant at $1 \%$ level.

** Significant at $5 \%$ leve1.

\subsection{Recreational Value of the MHN Park}

Table-6 shows consumer surplus and total recreational value of the MHN Park for the year 2002-03. The total recreational value equals the consumer surplus plus total cost of the visit. The annual monetary recreational value of the MHN Park is about Rs. 200 million (approximately US $\$ 3.47$ million). This is the value that the park yields every year for the economy. However, this is not the revenue of the park. This value is distinguished into consumer surplus of the visitors and total travel cost of the visitors. The total travel costs paid by the visitors go to transportation companies and agents for service providers such as hotels, restaurants, tourist agencies, etc. In addition, the total recreational value was also projected in the case of park improvements which amounted to Rs. 209 million (US \$ 3.63 million).

Table-6: Recreational Value of the MHN Park in 2002-03

\begin{tabular}{lrrrr}
\hline & \multicolumn{2}{c}{ Consumer Surplus } & \multicolumn{2}{c}{ Recreational Value } \\
& Actual & New Scenario & Actual & New Scenario \\
\hline Per Visitor (Rs.) & 231.0 & 319.0 & 1994.0 & 2081.4 \\
Total (Rs.million) & 23.2 & 32.01 & 200.1 & 208.9 \\
\hline
\end{tabular}

Source: Survey

The total actual consumer surplus was estimated to be Rs 23.3 million. This shows the value of the benefit that visitors gained by visiting the MHN Park. It also indicates the amount the visitors are willing to pay to enjoy the park's environmental resources such as air, water, fish, birds and animals, and scenic beauty. This figure, however, does not show the non-use value of the MHN Park. The annual consumer surplus in the case of an improved park quality scenario was projected as Rs. 32.01 million. 


\subsection{Simulation of Entrance Fee}

One of the policy goals of this study was to suggest an optimal entry fee that would maximize revenue for park authorities. We simulate the impact of increasing the entry fee from its current level of zero to Rs. 50 in Figure 3. Figure 3 shows an inverse relationship between the total annual number of visitors and the entrance fee. That is, when fees increase, visits decline. This is no different from the typical demand curve for any other good.

Figure 4 shows the total revenues to be generated from imposing various levels of entry fees. The data show that if a sum of Rs. 20 were determined as the entry fee, it would generate the maximum total revenue (i.e., Rs. 10.8 million) annually. According to this figure, the total revenue to be generated from entry fees would constitute $4 \%$ of the entire budget for the environment sector. Although the budget allocated for MHN Park was not reported accurately by the Park authorities, it is estimated that money generated from a park entry fee would constitute a significant proportion of the park budget. The Figure shows that the total revenue rises initially as the entry fee is enhanced from zero to Rs. 15, reaches its maximum at a fee of Rs. 20, and declines thereafter, implying that Rs. 20 would be an optimal entrance fee. The figure also reveals the fact that as entry fees increase, the consumer surplus declines. Initially, it is Rs. 969 per person when the entrance fee is zero and declines to Rs. 10 when the entrance fee is Rs. 50 per visit. When the entrance fee is Rs. 20, the consumer surplus is Rs. 210.

Figure-3: Visitors of MHNP Distinguished by WTP at Different Entrance Free

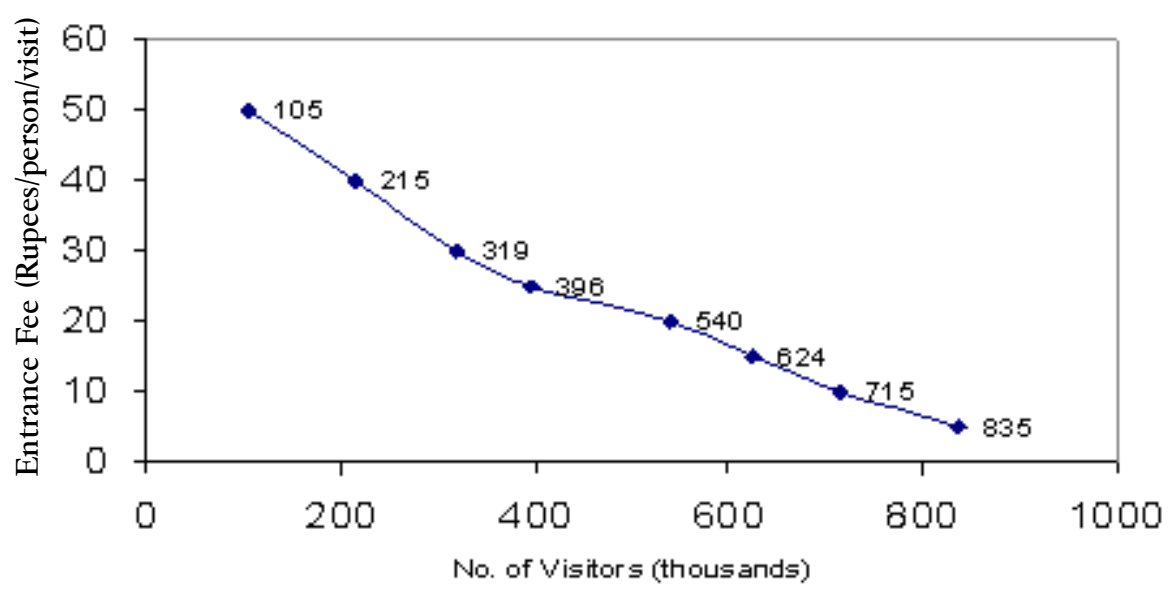


Ideally, we would have liked to compare revenues generated from the entry fee with the costs of improvements in park quality. But, in the absence of reliable cost estimates ${ }^{4}$ for park improvements, the present study could not make such a comparison. The recommendation that the entry fee be set at Rs. 20 is based on revenue and consumer surplus as well as the researcher's own observations.

Figure-4: Entrance Fee, Total Revenue and Consumer Surplus

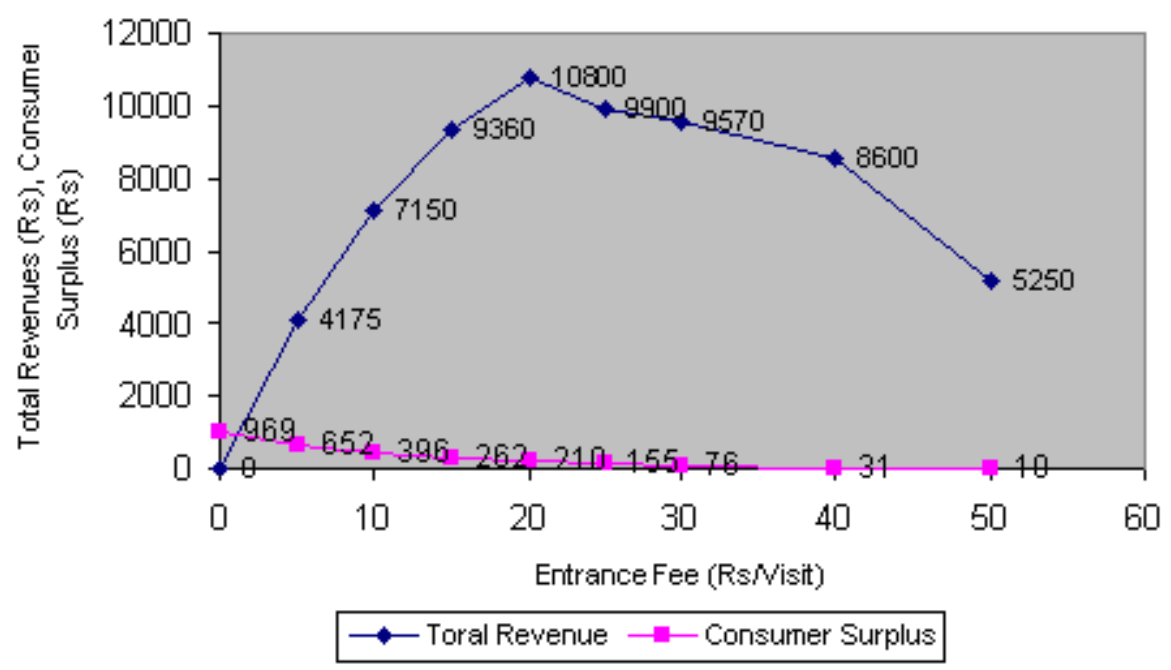

\section{Conclusions and policy implications}

In the wake of growing eco-tourism and the increasing interest on the part of NGOs and governments in natural resource conservation, nonmarket valuation techniques are needed to estimate the economic benefits of environmental resources such as national parks in these areas. The present study used the individual travel cost model (ITCM) for analyzing and measuring the total recreational value of the MHN Park.

Using the ITCM, the consumer surplus per visit was estimated at Rs. 231 and the recreational benefit per visit was about Rs.1,994. The total annual consumer surplus was estimated at Rs.23.2 million and total recreational value at Rs.200.1 million. Using the ITCM, linear and semi-log demand curves were estimated. Own-price, cross-price and income

\footnotetext{
${ }^{4}$ Although a number of attempts were made at an official level to inquire about the costs of improvements, it was impossible to get such estimates from the relevant officials. No one was in a position to provide such information. Thus, we could not simulate cost estimates of park improvement vis-à-vis total revenue and consumer surplus.
} 
elasticities of demand for the MHN Park were also estimated. The MHN Park is highly own-price and income elastic. The demand curves show that if the quality of the MHN Park is improved, it will attract more visitors and generate more revenues. This calls for the government to reallocate the budget for park management so that total recreational benefits of the park may be increased.

The MHN Park constitutes a valuable environmental resource. Although, at present the visitors do not pay any entrance fee, there is a large consumer surplus of welfare to be gained from the existence of the Park. In the future, if the number of visitors to the MHN Park increases, it would, it is expected, become more valuable. Although the estimated recreational value is only one aspect of the total value of the Park, it indicates that with proper conservation and management, tourism can be a significant source of benefits.

This study constitutes the first published estimate of the economic value of National Parks and other environmental resources in Pakistan. This type of valuation has implications for management at the MHN Park as well as other parks at risk.

The MHN Park has high values from both the use (i.e., recreational and tourism, educational and scientific research) and non-use values (i.e., genetic resources, and known and unknown future uses of ecological functions).

Governments at various levels are now the common planning units for natural resource management and are seriously considering the plight of their natural resources and are developing management plans accordingly. Such plans require budgeting and support from different departments and agencies, but often lack economic justification to help decision-makers appreciate what they are supporting. In this regard, there is an effort to raise awareness among local and national government decision-makers of the value of park resources and what would be lost if they were destroyed or not properly managed for long-term sustainability. This information helps justify investments in management and protection at a level of government that is directly concerned with its natural resource base.

The focus of this study is the valuation of environmental resources and how this information can be used to improve planning to national parks management in Pakistan. Government planners envision the MHN Park as an eco-tourism destination. It is representative of a number of national parks in Pakistan. It is in need of improved management so that economic and 
other benefits can be restored and enhanced. The MHN Park can generate enormous economic value through recreation. Keeping in view the large amount of consumer surplus and recreational value of the MHN Park, the Federal and provincial level governments can justify larger annual budget allocations for the management of natural resources.

Alternatively, the government may also consider using an entry fee to the MHN Park. The generated 'user value' of the park provides a guideline for the possible introduction of entrance fees and makes a strong argument for sustaining the area, as it has been demonstrated that benefits derived are large. In addition, the estimated value may also help in promoting the protection of other natural areas, and are thus presumably even more dependent on fair decision-making within the policy arena. Since the consumers (visitors) are willing to pay much higher than they actually pay for Park visitation, an entry fee of about Rs. 20 per person may be used. This would generate a great deal of money that could be used for improving park management.

The study showed that the visitors were willing to pay more than what they actually pay and that an entrance fee of Rs.20 per person per visit would generate sufficient amount of money to be used for park improvement. This, however, would reduce the overall consumer surplus. Thus, the drawback of this would be that the poor will be negatively affected as they would be less able to visit the park if an entrance fee were charged.

Critical issues remain to be explored further before the recommended policy for the benefit value capture can be fully realized. These include policy procedures and the process for implementation, including information sharing and consultation. The administrative organization for implementation and enforcement will also require investigation. 


\section{References}

Abala, D.O., 1987, 'A theoretical and empirical investigation of the willingness to pay for recreational services: a case study of Nairobi national park', Eastern Economic Review 3: 271-292.

Arin, T. and E. Sills, 2001, 'Developing Tourism to National Parks in the Republic of Georgia', World Bank, Washington, D.C.

Baldares, M.J., and J.G. Laarman, 1990, 'Derechos de Entrada a las Areas Protegidas de Costa Rica', Ciencias Economicas 10: 63-76.

Bateman, I.J. and K.G. Willis (eds.), 1999, Valuing Environmental Resources: Theory and Practice of the Contingent Valuation Method in the US, EU, and Developing Countries, New York: Oxford University Press.

Beal, D.J., 1995, 'Sources of variation in estimates of cost reported by respondents in trave1 cost surveys', Australian Journal of Leisure and Recreation 5(1): 3-8.

Chase, L., D. Lee, W. Schulze, and D. Anderson, 1998, 'Ecotourism demand and differential pricing of national park access in Costa Rica', Land Economics 74(4): 466-482.

Cummings, R.G., D.S. Brookshire, and W.D. Schulze, 1986, Valuing Environmental Goods: An Assessment of the Contingent Valuation Method, Savage, MD: Rowman and Littlefield Publishers.

Durojaiye, B.O. and A.E. Ipki, 1988, 'The monetary value of recreational facilities in a developing country: a case study of three centres in Nigeria', Natural Resources Journal 28: 315-328.

Echeverria, J., M. Hanrahan, and R. Solorzano, 1995, 'Valuation of nonpriced amenities provided by the biological resources within the Monteverde cloud forest preserve, Costa Rica', Ecological Economics 13: 43-52.

Freeman, A. Myrick III, 1993, The Measurement of Environmental and Resource Values: Theory and Methods, Washington, D.C: Resources for the Future, Inc. 
Garrod, Guy and K.G. Willis, 1999, Economic Valuation of the Environment: Methods and Case Studies, Cheltenham, UK and Northampton, MA, USA: Edward Elgar.

Grandstaff, S. and J.A. Dixon, 1986, 'Evaluation of Lumpinee Park in Bangkok, Thailand', in J.A. Dixon and M.M. Hufschmidt, eds., Economic Valuation Techniques for the Environment: A Case Study Workbook, Baltimore: John Hopkins University Press.

Himayatullah, 2003, 'Valuation of environmental resources: a case study of Margalla Hills National Park in northern Pakistan', SANDEE Research Report Series, South Asian Network for Development and Environmental Economics.

Isangkura, A., 1998, 'Environmental valuation: an entrance fee system for national parks in Thailand', EEPSEA Research Report Series, Economy and Environment Program for Southeast Asia, Tanglin, Singapore.

Kaosa-ard, M., D. Patmasiriwat, T. Panayotou, and J.R. Deshazo, 1995, 'Green financing: valuation and financing of Khao Yai National Park in Thailand', Thailand Development Research Institute, Bangkok.

Lansde11, N. and L. Gangadharan, 2001, 'Comparing trave1 cost models and the precision of their consumer surplus estimates: Albert Park and Maroondah Reservoir', Department of Economics, The University of Melbourne, Melbourne, Victoria, Australia.

Lindberg, K. and R.L. Johnson, 1994, 'Estimating demand for ecotourism sites in developing nations', Trends 31: 10-15.

Loomis, J.B. and R.G. Walsh, 1997, Recreation Economic Decisions: Comparing Benefits and Costs, Venture Publishing, State College, PA.

McConnell, K.E., 1992, 'On-site time in the demand for recreation', American Journal of Agricultural Economics 74: 918-925.

Moran, D., 1994, 'Contingent valuation and biodiversity: measuring the user surplus of Kenyan protected area', Biodiversity and Conservation 3: 663-684. 
Mungatana, E.D. and S. Navrud, 1994, 'Environmental valuation in developing countries: the recreational value of wildlife viewing', Ecological Economics 11: 135-151.

Nam, P.K. and T.V.H. Son, 2001, 'Analysis of the recreational value of the coral-surrounded Hon Mun islands in Vietnam', EEPSEA Research Report Series, Economy and Environment Program for Southeast Asia, Tanglin, Singapore.

Nillesen, E., 2002, 'The travel cost approach: an application to Bellenden Ker National Park', An Unpublished Thesis Submitted to the School of Economics, University of Queensland, Australia.

Pearse, P.H., 1968, 'A new approach to the evaluation of non-priced recreational resources', Land Economics 11: 135-151.

Scheaffer, R.L., W. Mendenhall III and R.L. Ott 1996, Elementary Survey Sampling, ( $5^{\text {th }}$ edition), Duxbury Press, USA.

Seenprachawong, U., 2001, 'An economic analysis of coral reefs in the andaman sea of Thailand', EEPSEA Research Report Series, Economy and Environment Program for Southeast Asia, Tanglin, Singapore.

Seller, C. J.R. Stoll and J. Chavas, 1985, 'Validation of empirical measures of welfare change: a comparison of non-market techniques', Land Economics 61(2): 156-175.

Shultz, S., J. Pinnazo, and M. Cifunetes, 1997, 'Opportunities and limitations of contingent valuation surveys to determine national park entrance fees: evidence from Costa Rica', Selected Papers presented at Annual Meetings of American Agricultural Economic Association, Toronto, Canada.

Smith, V.K., W.H. Desvousges and M.P. McGiveny, 1983, 'The opportunity cost of travel time in recreation demand models', Land Economics 59: 259-278.

Tobias, D. and R. Mendelssohn, 1991, 'Valuing ecotourism in a tropical rain-forest reserve', $A M B I O$ 20: 91-93.

Ward, F.A. and Diana Beal 2000, Valuing Nature with Travel Cost Models: A Manual. (New Horizons in Environmental Economics), Cheltenham, UK and Northampton, MA, USA: Edward Elgar. 
Wennergen, E.B., 1964, 'Valuing non-market priced recreational resources', Land Economics 40: 234-241.

World Resource Institute, 1996, World Resources: A Guide to the Global Environment (The Urban Environment) 1996-97, Oxford and New York: Oxford University Press. 